\title{
A Study of Training and Development at Private Educational Institutions- with special reference to Malwa Region- Punjab
}

\author{
*Ms Niti Prabhakar, \\ Faculty, Chandigarh Business School, Landran, \\ Mohali
}

\begin{abstract}
This paper addresses the main issues of training and development for private sector particularly educational institutions. This Paper has been made to understand how training and development in private educational Institutions make a difference in the working style of employees. The involvement of the private sector to foster the improvement of the workforce can affect the entire economy. The operations of the companies in the formulation and implementation of the training is having its own potential to grow as a strategy. This provided opportunity to the professionals deserves an upgrading approach into their skills and to their careers. The paper is based on the author's personal experience with more than 100 different training activities. The author has also had in-depth conversations with hundreds of employees and employers of private educational institutions.
\end{abstract}

\section{INTRODUCTION}

The study talks about the training and development in theoretical as well as new concepts, which are in trend now.

Training refers to the teaching or learning activities done for the primary purpose of helping members of an organization to acquire and apply the knowledge skills, abilities, and attitude needed by that organization and apply the same. Broadly speaking, training is the act of increasing the knowledge and skill of an employee for doing a particular job.

A successful training development program must include identification of training needs, establishment of training objectives, and selection of appropriate participants, lecturers, training materials, and instructional methods. All of these must be well thought out before training begins. Employee training tries to improve skills, or add to the existing level of knowledge so that employee is better equipped to do his present job, or to prepare him for a higher position with increased responsibilities. However individual growth is not an ends in itself. Organizational growth need to be measured along with individual growth. So it is high time for the organizations to realize that "train and retain is the mantra of new millennium." It is now necessary to raise the skill levels and increase the versatility and adaptability of employees.

\section{OBJECTIVES OF THE STUDY}

The specific objectives are:

1. To examine the effectiveness of training in overall development of skills of workforce.

2. To examine the impact of training on the workers.

3. To study the changes in behavioral pattern due to training.

4. To measure the differential change in output due to training.

5. To compare the cost effectiveness in implanting training programmes.

\section{SCOPE OF THE STUDY}

**Ms Rupinder Kaur,

Faculty, Vidya Sagar College of Management and Technology, Patiala

The scope of the study covers in depth, the various training practices, modules, formats being followed and is limited to the private Coaching Institutes and its employees. The different training programmes incorporated and facilitated in these institutes through its faculties, outside agencies or professional groups. It also judges the enhancement of the knowledge \& skills of employees and feedback on its effectiveness.

\section{TRAINING AND DEVELOPMENT}

It is a subsystem of an organization. It ensures that randomness is reduced and learning or behavioral change takes place in structured format.

- It's not what you want in life, but it's knowing how to reach it

- It's not where you want to go, but it's knowing how to get there

- It's not how high you want to rise, but it's knowing how to take off

- It may not be quite the outcome you were aiming for, but it will be an outcome

- It's not what you dream of doing, but it's having the knowledge to do it

- It's not a set of goals, but it's more like a vision

- It's not the goal you set, but it's what you need to achieve it

\section{IMPORTANCE OF TRAINING AND} DEVELOPMENT

$>$ Optimum Utilization of Human Resources - It helps in optimizing the utilization of human resource that further helps the employee to achieve the organizational goals as well as their individual goals.

$>$ Development of Human Resources - It helps to provide an opportunity and broad structure for the development of human resources' technical and behavioral skills in an organization. It also helps the employees in attaining personal growth.

$>$ Development of skills of employees - It increases the job knowledge and skills of employees at each level. It helps to expand the horizons of human intellect and an overall personality of the employees

$>$ Productivity - It helps in increasing the productivity of the employees that helps the organization further to achieve its long-term goal

$>$ Team spirit - It develops the sense of team work, team spirit, and inter-team collaborations. It helps in inculcating the zeal to learn within the employees

$>$ Organization Culture - It develops and improves the organizational health culture and effectiveness. It helps in creating the learning culture within the organization.

$>$ Organization Climate - It builds the positive perception and feeling about the organization. The employees get these feelings from leaders, subordinates, and peers. 
$>$ Quality - Training and Development helps in improving upon the quality of work and work-life.

$>$ Healthy work-environment -It helps in creating the healthy working environment. It also helps to build good employee, relationship so that individual goals aligns with organizational goal.

$>$ Health and Safety - Training and Development helps in improving the health and safety of the organization thus preventing obsolescence.

$>$ Profitability - It leads to improved profitability and more positive attitudes towards profit orientation. It also aids in organizational development i.e. Organization gets more effective decision making and problem solving. It helps in understanding and carrying out organizational policies.

\section{TRAINING AND HUMAN RESOURCE}

\section{MANAGEMENT}

The HR functioning is changing with time and with this change, the relationship between the training function and other management activity is also changing. The training and development activities are now equally important with that of other HR functions. Gone are the days, when training was considered to be futile, waste of time, resources, and money. Now-a-days, training is an investment because the departments such as, marketing \& sales, HR, production, finance, etc depends on training for its survival. If training is not considered as a priority or not seen as a vital part in the organization, then it is difficult to accept that such a company has effectively carried out HRM.

Training actually provides the opportunity to raise the profile development activities in the organization to increase the commitment level of employees and growth in quality movement (concepts of HRM), senior management team is now increasing the role of training. Such concepts of HRM require careful planning as well as greater emphasis on employee development and long term education. Training is now the important tool of Human Resource Management to control the attrition rate because it helps in motivating employees, achieving their professional and personal goals, increasing the level of job satisfaction, etc. As a result training is given on a variety of skill development and covers a multitude of courses. Capital intensive and not dependent upon profit margins and profitability. Although training needs are identified much before training programmed actually commence but still some crucial points are left some unaddressed.

For example very little is done to know the opinion of the employee about training need identified for him as to what he feels about the same 99\% cases employee is nominated by higher authorities instead of chance being given to volunteer program under the notion that boss is always right and he knows the best off. Taking this in context there are many organization where some employee who are earmarked are regularly nominated to attend training program. "He is stressed out, why don't pack him up for a training program" approach.

\section{STAKEHOLDERS IN TRAINING}

There are three major stakeholders in training program

1. The Organization

2. The Trainee

3. The Trainer

Stakeholders in the training take a training plan forward, perhaps over a period of one year, and sets parameters and priorities for the implementation stage. General Questions, which are asked in relationships to the training systems, are:

- What type of training is required?

- Why the training is required?

-What is the budget of the training?

-What are the most sensitive and critical areas?

- How the training will be carried out?

- By whom the training program will be carried out?

- Where and when will the training program be carried out?

\section{METHODOLOGY OF THE STUDY}

$$
\begin{array}{ll}
> & \text { Interview } \\
> & \text { Preparation of the summary expressed } \\
> & \text { Recommendation of fall back site } \\
> & \text { Questionnaire design }
\end{array}
$$

\section{RESEARCH DESIGN}

To understand the training and development scenario at GREY MATTERS and what the trainee really feels about the training they have undergone and further what kind of training they look for. Do they really look for any kind of training or not? To study the above aspect we covered almost about 100 people from almost all the branches at of the company grey matters

\section{TOOLS USED FOR DATA COLLECTION}

$>$ Primary data collected through questionnaires and informal interviews.

Secondary data collected through magazines, journals, websites, and other corporate publications

\section{PROCEDURE FOR DATA COLLECTION}

$>$ Communication, asking questions and receiving a response in person

$>\quad$ Visiting the various organizations, libraries, internet and also preparation of the questionnaire.

\section{DATA ANALYSIS AND INTERPRETATIONS}

Q1.Your Organization considers training as a part of organizational strategy. Do you agree with this statement?

\begin{tabular}{|l|c|c|}
\hline Response & No. of Respondents & Percentage \\
\hline Agree & 52 & 52 \\
\hline Disagree & 4 & 4 \\
\hline Partly Agree & 16 & 16 \\
\hline Can't Say & 28 & 28 \\
\hline Total & 100 & 100 \\
\hline
\end{tabular}




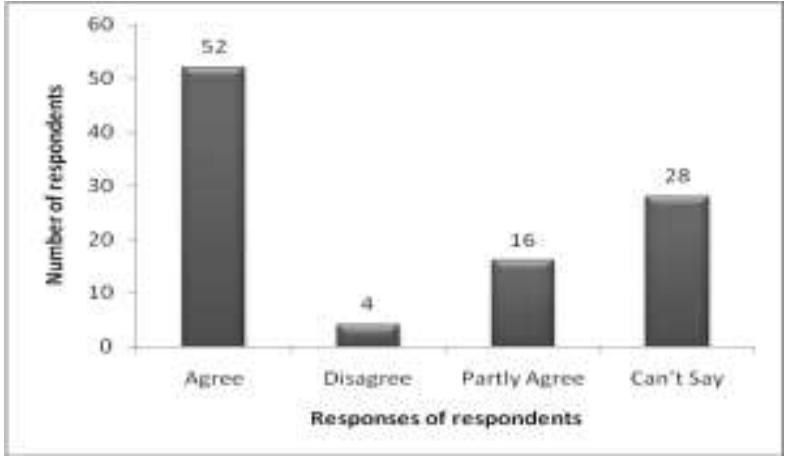

\section{Interpretation:-}

The above graph indicates that Organization considers training as a part of organizational strategy.

Q 2. How many training programmes will you attend in a year?

\begin{tabular}{|l|c|c|}
\hline $\begin{array}{c}\text { Number of } \\
\text { Training } \\
\text { Programmes }\end{array}$ & $\begin{array}{c}\text { No. of } \\
\text { respondents }\end{array}$ & Percentage \\
\hline Less than 10 & 56 & 56 \\
\hline $10-20$ & 8 & 8 \\
\hline $20-40$ & 12 & 24 \\
\hline More than 40 & 100 & 12 \\
\hline Total & & 100 \\
\hline
\end{tabular}

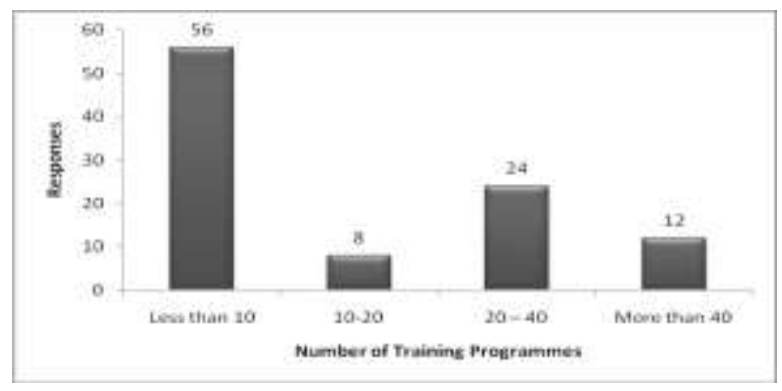

\section{INTERPRETATION:-}

The above chart indicates that less training programmes are held in the organization.

Q 3. To whom the training is given more in your organization?

\begin{tabular}{|l|c|c|}
\hline $\begin{array}{c}\text { Persons who got } \\
\text { Training }\end{array}$ & $\begin{array}{c}\text { No. of } \\
\text { respondents }\end{array}$ & Percentage \\
\hline Senior staff & 12 & 12 \\
\hline Junior staff & 20 & 20 \\
\hline New staff & 24 & 52 \\
\hline $\begin{array}{l}\text { Based on } \\
\text { requirement }\end{array}$ & 100 & 100 \\
\hline Total & 52 & \\
\hline
\end{tabular}

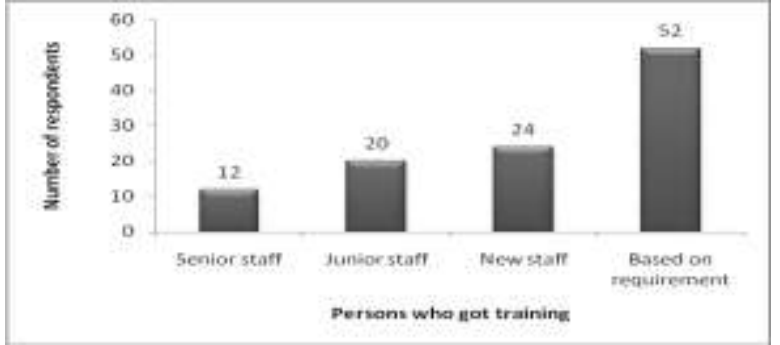

\section{INTERPRETATION:-}

Training is provided on the basis of requirement.

Q 4. What are all the important barriers to Training and Development in your organization?

\begin{tabular}{|l|c|c|}
\hline \multicolumn{1}{|c|}{$\begin{array}{c}\text { Barriers to } \\
\text { Training and } \\
\text { Development }\end{array}$} & $\begin{array}{c}\text { No. of } \\
\text { respondents }\end{array}$ & Percentage \\
\hline Time & 20 & 20 \\
\hline Money & 16 & 16 \\
\hline $\begin{array}{l}\text { Lack of interest by } \\
\text { staff }\end{array}$ & 24 & 24 \\
\hline $\begin{array}{l}\text { Non-availability of } \\
\text { skilled trainer }\end{array}$ & 40 & 40 \\
\hline Total & 100 & 100 \\
\hline
\end{tabular}

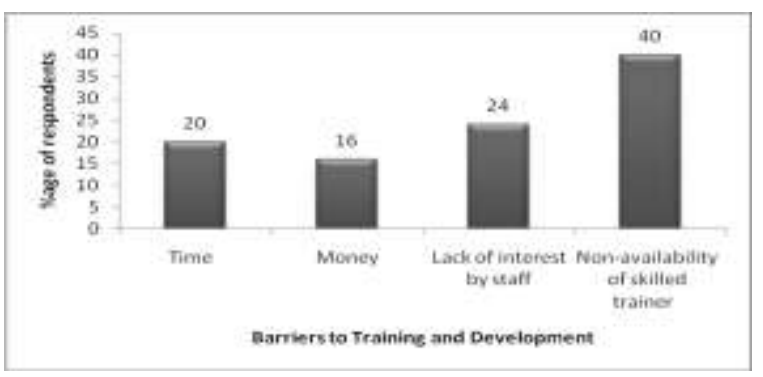

INTERPRETATION:-

The above graph indicates that the important barriers to Training and Development in the organization are Nonavailability of skilled trainers.

Q 5. Enough practice is given for us during training session? Do you agree with this statement?

\begin{tabular}{|l|c|c|}
\hline Responses & $\begin{array}{c}\text { No. of } \\
\text { respondents }\end{array}$ & Percentage \\
\hline $\begin{array}{l}\text { Strongly } \\
\text { Agree }\end{array}$ & 56 & 56 \\
\hline Agree & 8 & 8 \\
\hline $\begin{array}{l}\text { Somewhat } \\
\text { agree }\end{array}$ & 24 & 24 \\
\hline Disagree & 12 & 12 \\
\hline Total & 100 & 100 \\
\hline
\end{tabular}




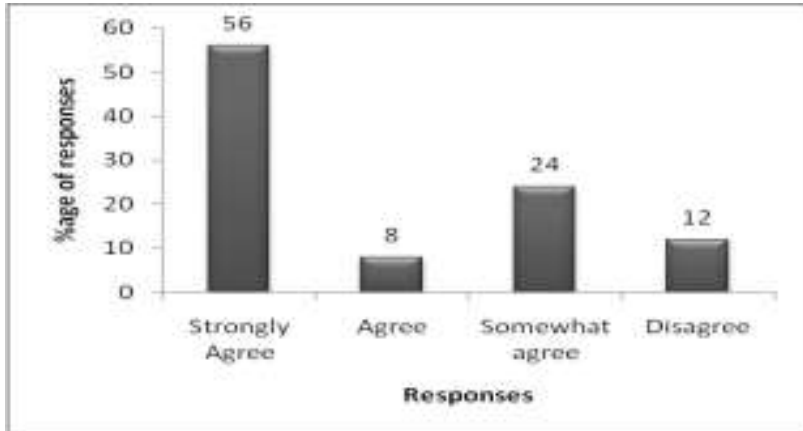

\section{INTERPRETATION:-}

This graph indicates that enough practice is given for employees during training sessions.

Q6. The training sessions conducted in your organization is useful. Do you agree with this statement?

\begin{tabular}{|l|c|c|}
\hline \multicolumn{1}{|c|}{ Responses } & $\begin{array}{c}\text { No. of } \\
\text { respondents }\end{array}$ & Percentage \\
\hline Strongly agree & 60 & 60 \\
\hline Agree & 20 & 20 \\
\hline Somewhat & 20 & 20 \\
\hline Disagree & 0 & 0 \\
\hline Total & 100 & 100 \\
\hline
\end{tabular}

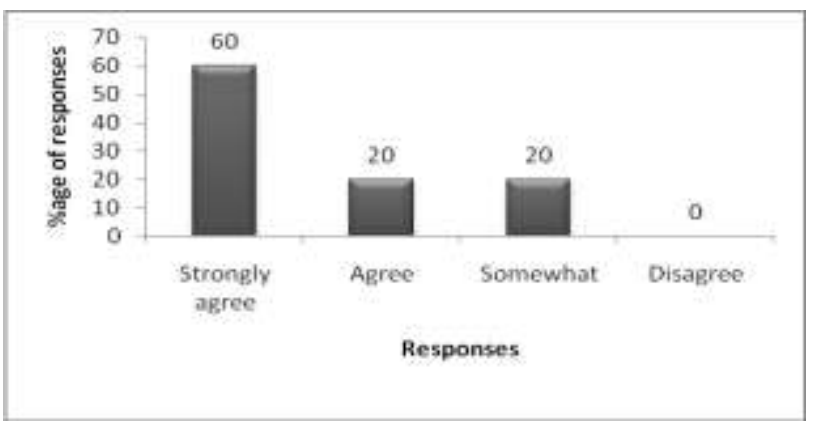

\section{INTERPRETATION:-}

The above graph indicates that the training sessions conducted in the organization is useful.

Q7. Employees are given appraisal in order to motivate them to attend the training. Do you agree with this statement?

\begin{tabular}{|l|c|c|}
\hline Respondents & No. of respondents & Percentage \\
\hline Strongly Agree & 56 & 56 \\
\hline Agree & 24 & 24 \\
\hline Somewhat & 12 & 12 \\
\hline Disagree & 8 & 8 \\
\hline Total & 100 & 100 \\
\hline
\end{tabular}

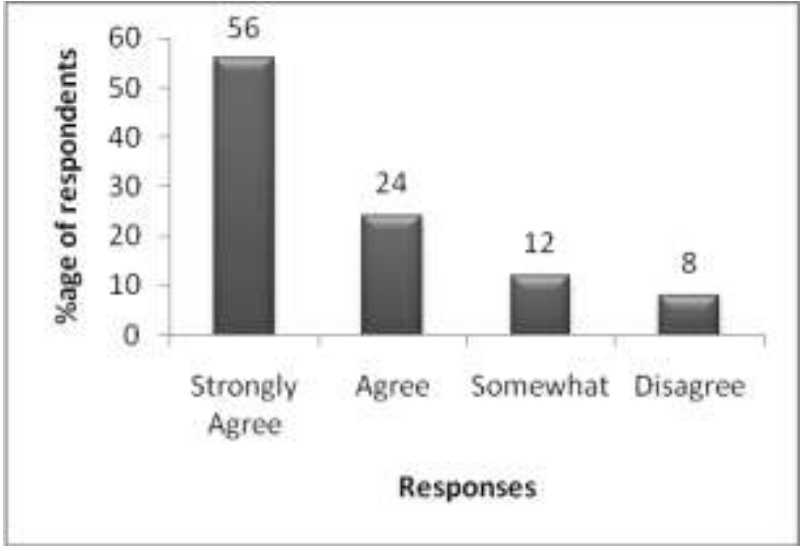

\section{INTERPRETATION:-}

The above graph shows that Employees are given appraisal in order to motivate them to attend the training.

Q8. What are the skills that the trainer should possess to make the training effective?

\begin{tabular}{|l|c|c|}
\hline Skills of Trainer & $\begin{array}{c}\text { No. of } \\
\text { respondents }\end{array}$ & Percentage \\
\hline Technical skills & 32 & 32 \\
\hline $\begin{array}{l}\text { People skills or Soft } \\
\text { skills }\end{array}$ & 24 & 24 \\
\hline $\begin{array}{l}\text { Generalist makes } \\
\text { better } \\
\text { managers Personnel } \\
\text { Specialist than }\end{array}$ & 24 & 24 \\
\hline $\begin{array}{l}\text { Fond of talking to } \\
\text { people }\end{array}$ & 100 & 100 \\
\hline \begin{tabular}{l} 
Total \\
\hline
\end{tabular}
\end{tabular}

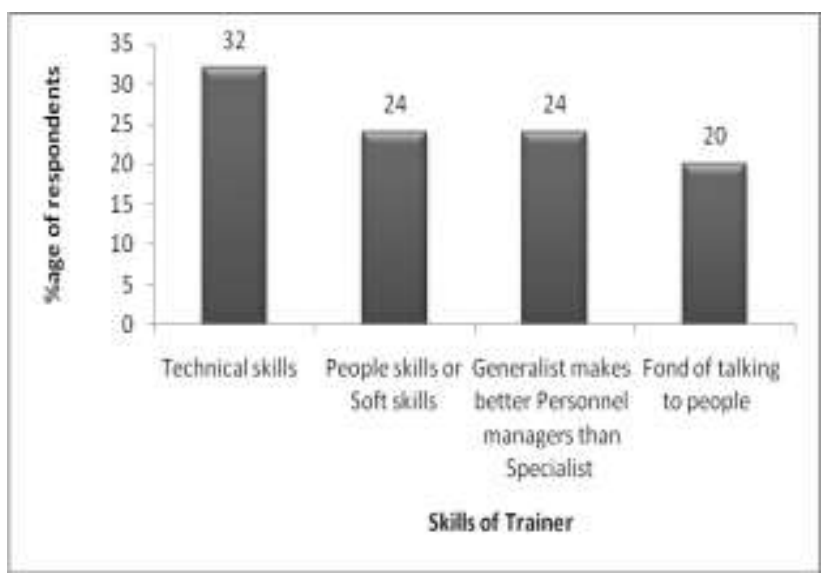

\section{INTERPRETATION:-}

The above graph indicates that the trainer should possess technical skills to make the training effective

Q9. What are the general complaints about the training session? 


\begin{tabular}{|l|c|c|}
\hline $\begin{array}{c}\text { Complaints about } \\
\text { the Training } \\
\text { Session }\end{array}$ & $\begin{array}{c}\text { No. of } \\
\text { respondents }\end{array}$ & Percentage \\
\hline $\begin{array}{l}\text { Take away precious time } \\
\text { of employees }\end{array}$ & 25 & 25 \\
\hline $\begin{array}{l}\text { Too many gaps between } \\
\text { the sessions }\end{array}$ & 40 & 40 \\
\hline $\begin{array}{l}\text { Training sessions are } \\
\text { unplanned }\end{array}$ & 15 & 15 \\
\hline Boring and not useful & 20 & 100 \\
\hline Total & 100 & 20 \\
\hline
\end{tabular}

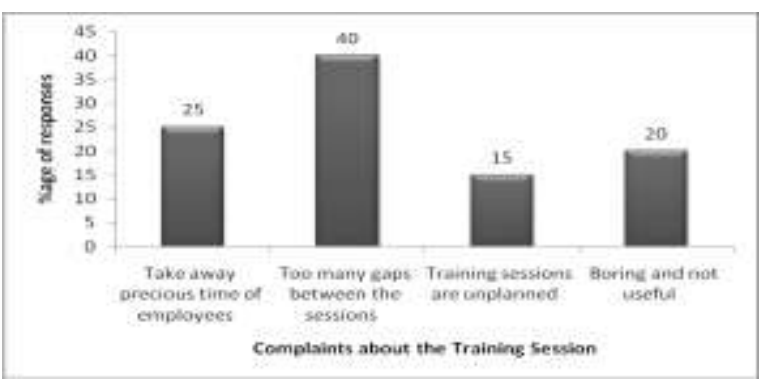

INTERPRETATION:-

The above graph indicates that there are two many gaps between the training sessions.

Q10. Reason for shortage of skilled man power at workplace are:

\begin{tabular}{|l|c|c|}
\hline $\begin{array}{c}\text { Reason for } \\
\text { shortage of skilled } \\
\text { man power }\end{array}$ & $\begin{array}{c}\text { No. of } \\
\text { respondents }\end{array}$ & Percentage \\
\hline Lack of planning & 20 & 20 \\
\hline $\begin{array}{l}\text { Lack of support from } \\
\text { senior staff }\end{array}$ & 40 & 40 \\
\hline $\begin{array}{l}\text { Lack of proper guidance } \\
\text { and training at } \\
\text { workplace }\end{array}$ & 32 & 32 \\
\hline $\begin{array}{l}\text { Lack of quality } \\
\text { education at primary and } \\
\text { secondary level }\end{array}$ & 8 & 8 \\
\hline Total & & \\
\hline
\end{tabular}

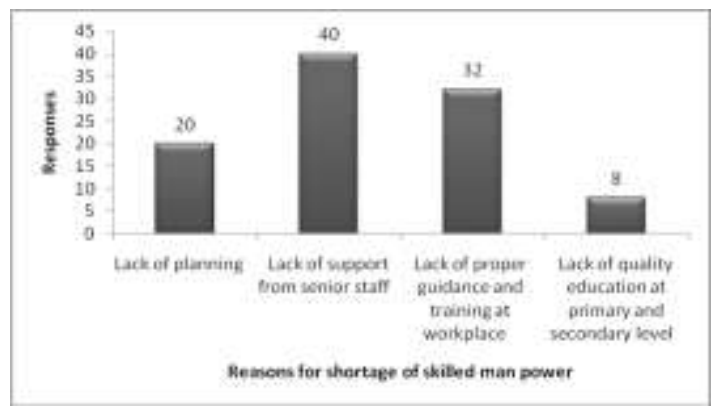

\section{INTERPRETATION:-}

The above graph indicates that reason for shortage of skilled man power at workplace are lack of support from senior staff.

\section{LIMITATIONS}

Every scientific study has certain limitations and the present study is no more exception. These are:

1. The terminology used in the subject is highly technical in nature and creates a lot of ambiguity.

2. All the secondary data are required were not available.

3. Respondents were found hesitant in revealing opinion about supervisors and management.

\section{SUGGESTIONS}

Under noted few suggestions cum conclusion can be taken as for implementation to reap further benefits.

$>$ Making training and development process and entirely in house activity to reduce cost.

$>$ It is found that the average age group of trainees are in their twenties or early thirties which signifies that the consumer durable industry need more of young blood as enthusiasm is an integral part of the industry.

$>$ The maximum emphasis is given to job instruction methods where the trainee are made to understand their job thoroughly and the role they are going to play in performing their job.

$>$ Lecture as well as the presentation is the major part of imparting the education and training them.

$>$ The training objective are in keeping with needs and abilities of the trainee and it is this that proves to be the major reason for success of the training as whole.

$>$ The trainee fill the feedback form and from time to time test are conducted to know the gauge the effectiveness of training to employee to check their memory if they retain anything or not.

$>$ We think that time management is one of the thing on which Reliance Mobile team must emphasis so that there employee can be more productive as it was found during the visit to the corporate office people they lack in managing themselves.

$>$ Stress management training is more important for employee as it was observed that people are all the time in tension like situation as to how to do what to do when to do, no time and things like that which kept them tensed all time.

Last but not least behavioral training is more important as while doing the study it was found that people are less cooperative and outgoing to help out.

\section{REFERENCES}

Barron, J, Berger, M C \& Black, M (1997). How Well do we Measure Training? Journal of Labour Economics, 15, 507528.

Bassi, L \& Ahlstrand, A (1999). Second Annual Report on American Society for Training \& Development's Standards 
for Valuing Enterprises' Investments Training \& Development, May

Supplement.

Becker, G.S. (1975). Human Capital: A Theoretical Analysis with Special Reference to Education, Columbia University Press, New York.

Collett, R. (1998). Modern Approaches in Training and Development in the New Zealand Public Sector (unpublished SSC paper for presentation to Hong Kong Civil Service Seminar)

Decision Research Ltd. (1997). Report of Survey of Training 1997: Findings of Research Conducted for New Zealand Employers Federation, August 1997.

Dwyer, M. (2000). Options for Improving Information on Job-Related Education and Training (unpublished report prepared for N.Z. Department of Labour)

Gobbi, M (1998). Participation in Post-compulsory Education and Training, Labour Market

Bulletin, $1 \& 2,108-126$

Interdepartmental Working Group on Ownership (1995). Taking Care of Tomorrow, Today:

A Discussion of the Government's Ownership Interest, SSC, Wellington

Investors in People (2000). Overview of the Investors in People Standard, IIP UK, London

Isaksson, C (1997). Survey of Benchmarking Activities, OECD/PUMA, Paris

Jennings, P (1996). Employer-sponsored Training in Canada: Evidence from the 1994 Adult

Education and Training Survey, Human Resources Development Canada, Quebec

Kirkpatrick, D L (1994). Evaluating Training Programs. The Four Levels, Berret-Koehler Publishers, San Francisco

Kirkpatrick, D L (1996). Great Ideas Revisited: Revisiting Kirkpatrick's Four-Level Model, Training and Development, $50,1,54-57$

Labour Party (July 1999). 21st Century Skills (www.labour.org.nz/Infocentre1/Policies/IndustryTrainingpol. html).

Labour Party (November 1999). Labour on the State Sector (www.labour.org.nz/Infocentre1/Policies/statesectorpol.html).

Management Development Centre (1997). Secondment Guidelines for Career Development

and the Management Development Centre Secondment Service MDC, Wellington.

Management Development Centre (1999). Inter-Agency Project Work for Senior Management Career Development Guidelines, MDC, Wellington
Office of the Controller and Auditor-General (1999). The Accountability of Executive Government to Parliament, OAG, Wellington

Organisation for Economic Cooperation \& Development (1991). Enterprise-related Training,

OECD Employment Outlook, OECD, Paris.

Organisation for Economic Cooperation \& Development (1997). Manual for Better Training

Statistics: Conceptual, Measurement and Survey Issues, OECD, Paris.

Robertson, A. (1999). Are You Getting Value for Money from your Tax Dollars? Evaluation of

Training in Government Departments in New Zealand, Australasian Evaluation Society 1999

Conference Proceedings.

Silva, L.D.S (2000). A Study of Factors Influencing Human Resource Development Practices

and their Effects on some Public Sector Organisations in New Zealand (unpublished paper for Diploma in Human Resource Management, Victoria University of Wellington).

State Services Commission (1993). Survey of Training Provision in Public Service Departments, SSC,Wellington.

State Services Commission (1996). Strategic Human Resource Capability in the Public Service: Interviews with Public Service Chief Executives and Selected other

Commentators, SSC,Wellington.

State Services Commission (1997). Strategic Human Resource Capability Issues in the Public

Service: Full Project Report with Recommendations, SSC, Wellington.

State Services Commission (1999). Measuring Human Resource Capability in the Public Service, Occasional Paper 13, SSC, Wellington.

Stern, J \& Ritzen, J M M (1991). Market Failure in Training? New Economic Analysis and Evidence on Training of Adult Employees, Springer-Verlag, Berlin Heidleberg.

Sveiby, K. (1997). The New Organizational Wealth: Managing and Measuring Knowledgebase

Assets, Berrett-Koehler Publishers Inc, San Francisco CA

Veum, J (1996). Gender and Race Differences in Company Training, Industrial Relations, 35, 32-44

Yeabsley, J (1999). Strategic Development Branch Output Quality Review (unpublished review of policy papers from the Strategic Development Branch, SSC). 